\title{
ST
}

Science \& Technology

PAPER - OPEN ACCESS

Efektivitas Pendekatan Saintifik Dengan Menggunakan Media Macromedia Flash Terhadap Hasil Belajar Peserta Didik
Author
: Dina Hasibuan dkk.,
DOI
: $10.32734 /$ st.v2i1.356
Electronic ISSN
: 2654-7082
Print ISSN
: 2654-7074

Volume 2 Issue 1 - 2018 TALENTA Conference Series: Science \& Technology (ST)

This work is licensed under a Creative Commons Attribution-NoDerivatives 4.0 International License.

Published under licence by TALENTA Publisher, Universitas Sumatera Utara

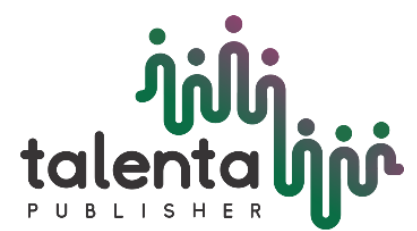




\title{
jibli

\section{Efektivitas Pendekatan Saintifik Dengan Menggunakan Media Macromedia Flash Terhadap Hasil Belajar Peserta Didik}

\author{
Dina Ananda Hasibuan ${ }^{\mathrm{a}}$, Ramlan Silaban ${ }^{\mathrm{b}}$, Rona Rezky M \\ ${ }^{a, b, c}$ Program Studi Pendidikan Kimia, Pascasarjana, Universitas Negeri Medan, Medan \\ *dinaanandahsb@gmail.com
}

\begin{abstract}
Abstrak
Penelitian ini bertujuan untuk mengetahui keefektifan hasil belajar siswa melalui pendekatan saintifik dengan menggunakan media Macromedia Flash dan tanpa pendekatan saintifik dengan menggunakan media Macromedia Flash pada topik Hidrolisis Garam. Populasi dalam penelitian ini adalah seluruh siswa kelas XI SMA Negeri 11 Medan tahun ajaran 2015/2016. Sampel yang digunakan pada penelitian ini diambil secara purposif sampling. Yang terdiri dari dua kelas, yakni satu kelas sebagai kelas eksperimen 1 melalui pendekatan saintifik menggunakan Macromedia Flash dan satu kelas sebagai kelas eksperimen 2 tanpa pendekatan saintifik dengan menggunakan Macromedia Flash. Masing-masing kelas terdiri dari 40 siswa. Hasil belajar siswa melalui pendekatan saintifik dengan menggunakan media Macromedia Flash lebih tinggi daripada hasil belajar siswa tanpa pendekatan saintifik menggunakan Macromedia Flash.
\end{abstract}

Kata Kunci : Saintifik, Macromedia Flash, Hidrolisis Garam

\section{Pendahuluan}

Perkembangan teknologi informasi dan komunikasi yang sedemikian pesatnya membuat manusia secara sengaja atau tidak sengaja telah dan akan berinteraksi terhadap teknologi, sehingga menciptakan kultur baru bagi semua orang dalam berbagai bidang tanpa terkecuali di bidang pendidikan [1] Pendidikan merupakan faktor yang sangat penting dalam menentukan masa depan suatu bangsa. Hal ini sejalan dengan misi pendidikan nasional yang ditetapkan Depdiknas 2005/2006 yaitu mewujudkan pendidikan yang mampu membangun insan Indonesia yang cerdas komprehensif meliputi cerdas spiritual, cerdas emosional dan sosial, cerdas intelektual dan cerdas jasmani [2].

Ilmu kimia adalah bagian pendidikan yaitu adalah pendidikan Ilmu Pengetahuan Alam (IPA) Ada tiga hal yang berkaitan dengan kimia yang tidak terpisahkan, yaitu kimia sebagai produk, kimia sebagai proses dan kimia sebagai sikap. Ketiga hal tersebut merupakan satu kesatuan yang tidak dapat terpisahkan, sebab tidak ada pengetahuan kimia tanpa proses yang menggunakan pikiran dan sikap saintifik [3]. Karakteristik konsep ilmu kimia berbeda dengan ilmu lainnya. Kimia berisi hitungan, fakta yang harus diingat, kosakata khusus, hukum-hukum yang mengkaitkan satu ide dengan ide lain yang harus dipahami secara benar dan tepat. Oleh sebab itu, pembelajaran kimia dan penilaian hasil belajar kimia harus memperhatikan karakteristik ilmu kimia tersebut [4].

Kimia merupakan salah satu cabang pelajaran MIPA yang masih banyak dianggap sulit. Mata pelajaran kimia merupakan produk pengetahuan alam yang berupa fakta, teori, prinsip, dan hukum dari proses kerja ilmiah. Jadi, dalam pelaksanaan pembelajaran kimia harus mencakup tiga aspek utama yaitu: produk, proses, dan sikap ilmiah [5]. Pendekatan saintifik adalah pendekatan pembelajaran yang mendorong peserta didik untuk melakukan keterampilan-keterampilan ilmiah seperti mengamati, menyanya, mengumpulkan informasi, mengorganisasi, dan mengkomunikasikan, sehingga untuk memperkuat pendekatan saintifik diperlukan adanya penalaran dan sikap kritis peserta didik dalam rangka pencarian dan berpikir secara ilmiah [6]. 
Ada dua unsur yang amat penting dalam suatu proses belajar mengajar yaitu pembelajaran dan media pembelajaran. Kedua aspek ini berkaitan. Pemilihan salah satu model pembelajaran tertentu akan mempengaruhi jenis media pembelajaran langsung, dan konteks pembelajaran termasuk karakteristik siswa. Meskipun demikian, dapat dikatakan bahwa salah satu fungsi utama media pembelajaran adalah sebagai alat bantu mengajar yang turut mempengaruhi iklim, kondisi, dan lingkungan belajar yang ditata dan diciptakan oleh guru [7].

Hasil dari penelitian Sharon Ainsworth bahwa ketika siswa belajar menggunakan media animasi, merupakan sesuatu yang sangat penting dalam memahami suatu informasi. Belajar menggunakan animasi dapat mengkondisikan dalam belajar sosial, dan dalam hal komunikasi untuk saling bekerja [8]. Hasil penilaian lain tentang penggunaan media yaitu dari Riyana Fathiyati diperoleh skor 1187 dari skor maksimal 1560 dengan presentase keidealan 79,13\% dan mempunyai kategori baik (B). Berdasarkan penilaian guru biologi dan respon siswa tersebut menunjukkan bahwa media pembelajaran berbasis Macromedia Flash tersebut layak digunakan sebagai sumber belajar mandiri untuk SMA/MA.

Berdasarkan uraian di atas, peneliti merasa tertarik untuk melakukan penelitian dengan judul " Efektivitas Pendekatan Saintifik Dengan Menggunakan Media Macromedia Flash Terhadap Hasil Belajar Peserta Didik".

\section{Metode}

\section{Lokasi Penelitian}

Penelitian ini telah dilaksanakan di Sekolah SMAN 11 Medan di Jalan Pertiwi No. 93 Medan.

Waktu Penelitian

Penelitian ini telah dilaksanakan pada bulan Desember-Mei 2016 di kelas XI IPA semester genap Tahun Ajaran 2015/2016.

\section{Populasi dan Sampel}

Populasi dalam penelitian ini adalah seluruh siswa kelas XI IPA SMAN 11 Medan sebanyak 7 kelas dengan jumlah siswa rata-rata 40 siswa tiap kelas. Sampel dalam penelitian ini sebanyak dua kelas yang diambil secara purposive sampling.

\section{Hasil dan Pembahasan}

Tes yang digunakan disusun sebagai instrumen penelitian, setelah di uji cobakan dengan memperhatikan validitas, reliabilitas, daya pembeda dan tingkat kesukaran soal dapat disimpulkan bahwa soal yang layak di ujikan dalam penelitian ini berjumlah 24 soal.

Setelah melihat analisis data dari tingkat kesukaran soal bahwa ke 24 soal yang valid ternyata ditemukan 4 soal yang memiliki tingkat kesukaran yang mudah. Sehingga, instrument tes yang dipakai berjumlah 20 soal.

Dalam penelitian ini, hasil belajar yang digunakan atau dianalisis peneliti adalah berupa hasil belajar (posttest). Sebelum kedua sampel diberikan perlakuan yang berbeda, terlebih dahulu diberikan tes awal yang bertujuan untuk mengetahui kemampuan awal masing-masing siswa pada kedua kelas, serta untuk mengetahui kedua kelas tersebut terdistribusi normal dan homogen. Selanjutnya dilakukan pembelajaran yang berbeda yaitu kelas eksperimen 1 dengan media Macromedia Flash dengan pendekatan saintifik, kelas eksperimen 2 dengan media Macromedia Flash. 
Tabel 1. Rata-Rata Nilai Hasil Belajar Siswa

\begin{tabular}{llll}
\hline \multirow{2}{*}{ Data } & Statistik & \multicolumn{2}{l}{ Kelas } \\
\cline { 2 - 4 } & & Eksperimen & Kontrol \\
\hline \multirow{3}{*}{ Pretest } & Rata-rata & 50,14 & 48,19 \\
\cline { 2 - 4 } & Standar Deviasi & 6,92 & 8,46 \\
\cline { 2 - 4 } & Varians & 47,84 & 71,65 \\
\cline { 2 - 4 } & Minimum & 35 & 25 \\
\cline { 2 - 4 } & Maksimum & 65 & 65 \\
\hline \multirow{3}{*}{ Posttest } & Rata-rata & 82,64 & 76,25 \\
\cline { 2 - 4 } & Standar Deviasi & 6,60 & 6,37 \\
\cline { 2 - 4 } & Varians & 43,55 & 60,54 \\
\cline { 2 - 4 } & Minimum & 70 & 90 \\
\cline { 2 - 4 } & Maksimum & 95 & 65 \\
\hline
\end{tabular}

Berdasarkan Tabel 1, maka dapat digambarkan perbedaan hasil perolehan rata-rata nilai pretest dan posttest kelas eksperimen 1 dan kelas eksperimen

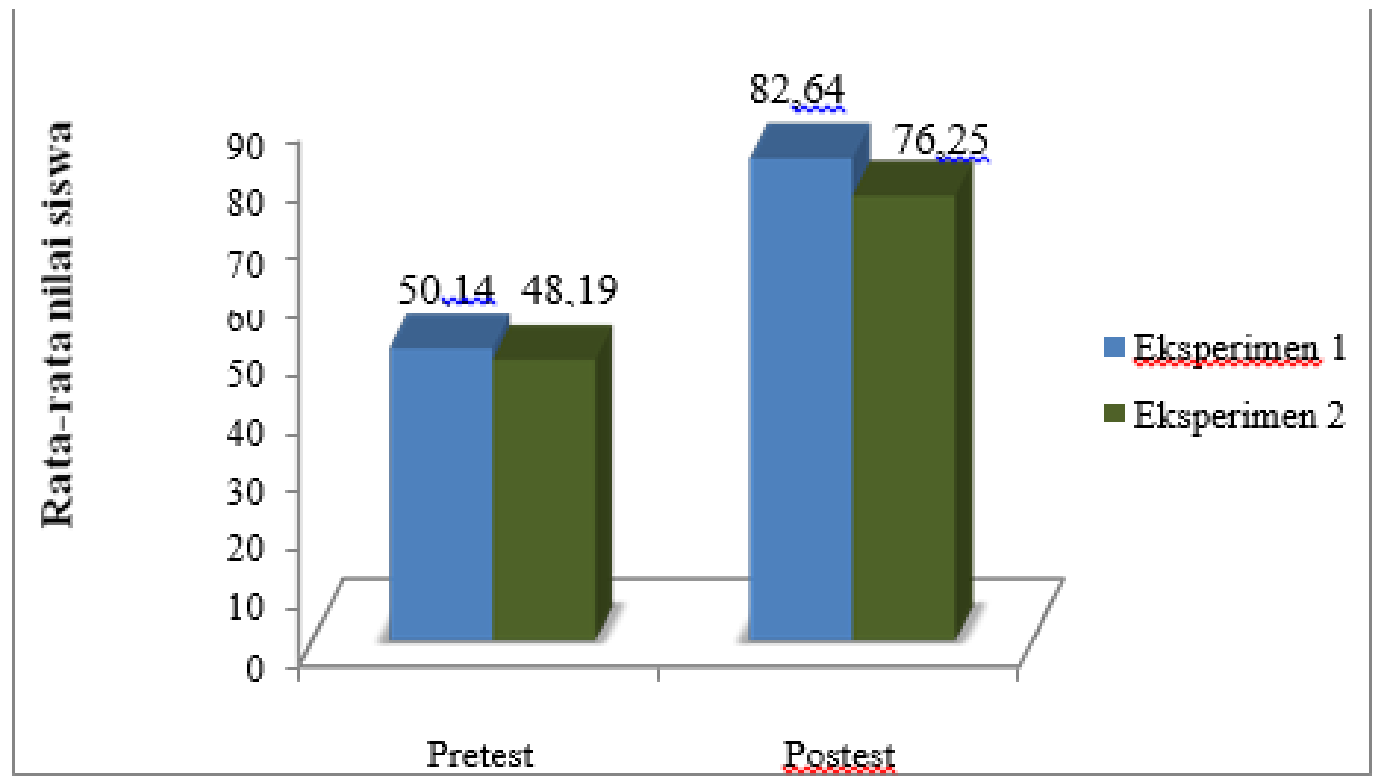

Gambar 1. Grafik Hasil Belajar

Penelitian ini diawali dengan pemberian tes awal (pretest) kepada kedua sampel kelas yaitu kelas eksperimen 1 dan kelas eksperimen 2. Tujuan dilakukan Pretest untuk mengetahui kemampuan awal siswa. Nilai pretest siswa yang diatas 50 lebih tinggi dari yang lain karena siswa tersebut ada mengikuti bimbingan belajar sehingga terjadinya peningkatan bukan semata-mata hasil perlakuan yang ditentukan. Ini merupakan keterbatasan penelitian.

Hasil analisa data diperoleh bahwa sebelum diberikan perlakuan yang berbeda kepada kelas sampel diperoleh bahwa rata-rata hasil belajar kimia siswa kelas eksperimen 1 50,14 dan setelah menggunakan 
pendekatan saintifik bermediakan Macromedia Flash diperoleh rata-rata hasil belajar kimia sebesar 82,64. Sedangkan, untuk siswa kelas eksperimen 2 sebelum dberikan perlakuan diperoleh rata-rata hasil belajar kimia sebesar 48,19 dan tanpa menggunakan pendekatan saintifik bermediakan Macromedia Flash hasil belajar sebesar 76,25

Hasil pengujian hipotesis diperoleh thitung $>$ tabel $=3,310>1,678$ dengan taraf signifikan $5 \% \quad(\alpha=0,05)$ atau dengan taraf kepercayaan $95 \%$ sehingga Ha diterima yang berarti hasil belajar kimia yang dibelajarkan dengan menggunakan pendekatan saintifik bermediakan Macromedia Flash lebih baik dibandingkan hasil belajar kimia siswa tanpa pendekatan saintifik.

\section{Kesimpulan}

Hasil belajar siswa yang diajarkan dengan pendekatan saintifik bermediakan Macromedia Flash lebih tinggi daripada hasil belajar siswa yang diajarkan dengan tanpa pendekatan saintifik bermediakan Macromedia Flash.

\section{Referensi}

[1] Darmawan, D. (2012). Teknologi Pembelajaran. Bandung: Remaja Rosdakarya.

[2] Depdiknas., (2006), Standar Kompetensi Mata Pelajaran Ilmu Pengetahuan Alam untuk Sekolah Menengah Pertama/Madrasah Tsanawiyah, Pusat Pendidikan Dasar Dan Menengah Direktorat Pendidikan Menegah Umum, Jakarta.

[3] Tiffanny D.M., Nina K., dan Emmawaty S. (2015). Efektivitas Pendekatan Saintifik Dalam Meningkatkan Kemampuan Membedakan Pada Materi Hidrolisis Garam. Jurnal Pendidikan dan Pembelajaran Kimia, Vol. 4, No.2 Edisi Agustus 2015,618-630

[4] Dali., (2013), Kajian Kemampuan Memahami Teori Asam Basa Pada Siswa Kelas XI IPA SMA Negeri 1 Limboto, Tesis, FMIPA Universitas Negeri Gorontalo, Gorontalo.

[5] Wasonowati, T., Redjeki.T., dan Ariani.D.S.R, (2014), Penerapan Model Problem Based Learning (PBL) Pada Pembelajaran Hukum-Hukum Dasar Kimia Ditinjau Dari Aktivitas dan Hasil Belajar Siswa Kelas X IPA SMA Negeri 2 Surakarta Tahun Pelajaran 2013/2014, Jurnal Pendidikan Kimia, 3.

[6] Asrul., (2014), Evaluasi Pembelajaran, Citapustaka Media, Medan

[7] Arsyad, A., (2007), Media Pembelajaran, Raja Grafindo, Jakarta.

[8] Fathiyati, R., (2008) Pengembangan Media Pembelajaran Biologi Berbasis Macromedia Flash Sebagai Sumber Belajar Bagi Siswa SMA/MA Kelas XI Semester 2 Materi Pokok Sistem Reproduksi, Skripsi, UIN Sunan Kalijaga, Yogyakarta. 